\title{
Work-Life Balance in the perception of Generation Y
}

\author{
Katarzyna Januszkiewicz (Ph.D.) \\ Faculty of Management, University of Lodz, ul. Matejki 22/26, Poland \\ Email: katarzynaj@uni.lodz.pl
}

\section{Doi:10.5901/mjss.2014.v5n27p264}

\section{Abstract}

The purpose of this article is to answer the question how far the perception of career success is unified by the global standard, and how much still remains under the influence of local patterns. The study included perceptions of work - life balance and the cost of this. This assumption was the basis for the design of own research, which summarizes the generally accepted ideas about selected aspects of the career of Gen Y, with the perception of Gen Y representatives from six countries (Polish, Austria, Spain, Portugal, Turkey and Russia).

Keywords: Career, work-life balance, Generation Y

\section{Introduction}

New constantly changing conditions of the professional functioning that are related to changes in the career model comprise, the reality in which grow up and shape their understanding of professional life representatives of Generation Y. This is the first group of employees, for whom the career model is built on the basis of global patterns and to whom cultural unification is attributed to[Pahl 2008; Bańka 2007]. It should be noted, however, that such an approach tending to ignore the local factors- over-simplifies reality and includes features of stereotype. Generation $Y$ in comparison to the previous groups of workers, to the significantly greater extent is vulnerable to the pressure of global factors, but still this is not total dependence and one can see the diversity arising from the functioning under the different local conditions (see Figure 1).

Figure 1. The influence of local and global factors subsequent generations of of workers

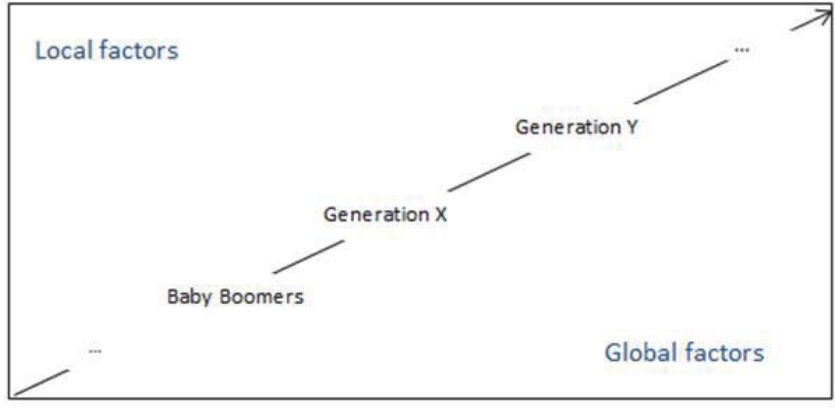

\section{Source: Own research}

To the factors of the local nature should be included among others- family of professional career models, directly available experience of their peers generation and socio-economic conditions in the given country; while to the global factors- publicly accessible career models, indirectly available experience of peer generation by means of social networking, and socio-economic conditions of the world economy. ${ }^{1}$

Assessment of the degree of determination of each category is not easy. It can be derived indirectly on the basis of a comparative analysis of the career scheme implemented by those individuals who were brought up in the diverse

1 Specified components certainly not cover the catalogue of factors belonging to each of these categories, but in the context of building career model should be considered as the most important. 
environment. This assumption became the basis for the design of a model of own research, which compares the generally accepted idea regarding selected aspects of career characteristic of Generation $Y$ to the perception of the given issue by the representatives of Generation $Y$ from six countries. The aim of this study is to answer the question of how far this perception is a unified global standard or to what extent it continues to be a under the influence of local/national standards. The perception of the work-life balance and the costs of professional success will be under our detailed analysis.

\subsection{Research Methods}

The presented research results are a part of a research project Success in the perception of future managers Comparative analysis, conducted in the years 2011- 2013 in five countries: Poland, Austria, Portugal, Spain, Turkey, Russia. Selection of the sample had an incidental character, the respondents were students of Management department, participating on the day of research in obligatory lectures for groups of the department. The study was conducted in the form of an anonymous questionnaire, about the aim of which the students were informed.

\subsubsection{Analysis Result}

The first research question concerned the perception of the proportion between private and professional life for people who have achieved professional success. In general, representatives of Generation Y noticed some risk to private life and contamination of time by professional issues (the median value for each country ranges from $50 \%$ to $40 \%$ ). However, detailed analysis within each group shows some differences. Most Spaniards, Polish and Russians have expressed the belief that while achieving success only $30 \%$ of the time is devoted to private matters, while $70 \%$ is taken up by professional issues (dominant 30\%). Similar indications, indicating the dominance of working life, was obtained in a group of Portuguese (dominant 40\%), while in the perception of young Austrians and Turks most frequently these two areas are skillfully harmonized by successful people (dominant $50 \%$ ).

Table 1. The proportion of work-life balance for individuals who have achieved professional success in the perception of the representatives of Generation $Y$

\begin{tabular}{|c|c|c|c|c|c|c|c|}
\hline Private life & Professional life & $\begin{array}{c}\text { Austria } \\
\mathrm{N}=81\end{array}$ & $\begin{array}{c}\text { Spain } \\
\mathrm{N}=136\end{array}$ & $\begin{array}{c}\text { Poland } \\
\mathrm{N}=111\end{array}$ & $\begin{array}{c}\text { Portugal } \\
\mathrm{N}=127\end{array}$ & $\begin{array}{c}\text { Russia } \\
\mathrm{N}=40\end{array}$ & $\begin{array}{c}\text { Turkey } \\
\mathrm{N}=48\end{array}$ \\
\hline $10 \%$ & $90 \%$ & $1 \%$ & $4 \%$ & $3 \%$ & $2 \%$ & $5 \%$ & $4 \%$ \\
\hline $20 \%$ & $80 \%$ & $4 \%$ & $9 \%$ & $10 \%$ & $10 \%$ & $3 \%$ & $0 \%$ \\
\hline $30 \%$ & $70 \%$ & $4 \%$ & $\mathbf{2 9} \%$ & $\mathbf{2 6} \%$ & $17 \%$ & $\mathbf{2 8} \%$ & $10 \%$ \\
\hline $40 \%$ & $60 \%$ & $5 \%$ & $16 \%$ & $24 \%$ & $\mathbf{3 1 \%}$ & $25 \%$ & $23 \%$ \\
\hline $50 \%$ & $50 \%$ & $\mathbf{4 6 \%}$ & $17 \%$ & $19 \%$ & $17 \%$ & $20 \%$ & $\mathbf{4 4 \%}$ \\
\hline $60 \%$ & $40 \%$ & $10 \%$ & $10 \%$ & $5 \%$ & $9 \%$ & $8 \%$ & $10 \%$ \\
\hline $70 \%$ & $30 \%$ & $12 \%$ & $5 \%$ & $7 \%$ & $6 \%$ & $10 \%$ & $6 \%$ \\
\hline $80 \%$ & $20 \%$ & $5 \%$ & $2 \%$ & $2 \%$ & $0 \%$ & $3 \%$ & $2 \%$ \\
\hline $90 \%$ & $10 \%$ & $2 \%$ & $1 \%$ & $0 \%$ & $2 \%$ & $0 \%$ & $0 \%$ \\
\hline brak odp. & & $11 \%$ & $7 \%$ & $4 \%$ & $6 \%$ & $0 \%$ & $0 \%$ \\
\hline & $100 \%$ & $100 \%$ & $100 \%$ & $100 \%$ & $100 \%$ & $100 \%$ \\
\hline & & & & & & \\
\hline
\end{tabular}

Source: Own research

The analysis of answers indicates the low level of similarity between the structures for all six nations (37\%). T-Chuprov Convergence factor indicates the mild correlation between the perception of the proportion of work/life balance depending on the country $(T=0.21)$. The lack of correlation with respect to gender $(T=0.03)$.

However, if compared in pairs some similarities can be observed (Table 2). Distribution of answers given by young Spaniards is characterized by a considerable resemblance to the answers given by the representatives of the generation $Y$ from Poland, Portugal and Russia ( $>0.8$ ). Similar resemblance of answers can be observed between the Polish, Portuguese and Russian. The exceptions are future managers from Austria and Turkey whose response is characterized 
by the lack of similarity of structures to other countries.

Table 2. Similarity index of structures

\begin{tabular}{|c|c|c|c|c|c|c|}
\cline { 2 - 7 } \multicolumn{1}{c|}{} & Austria & Spain & Poland & Portugal & Russia & Turkey \\
\hline Austria & - & & & & & \\
\hline Spain & $56 \%$ & - & & & & \\
\hline Poland & $51 \%$ & $\mathbf{8 6 \%}$ & - & & & \\
\hline Portugal & $55 \%$ & $\mathbf{8 2} \%$ & $\mathbf{8 6 \%}$ & - & & \\
\hline Russia & $52 \%$ & $\mathbf{8 2} \%$ & $\mathbf{8 9} \%$ & $77 \%$ & - & - \\
\hline Turkey & $72 \%$ & $65 \%$ & $68 \%$ & $68 \%$ & $73 \%$ & \\
\hline
\end{tabular}

Source: Own research

With respect to the next research question, regardless of the country of origin, students seem to be aware of the costs of achieving professional success for an individual (see Table 3).

Table 3. Awareness of the cost of professional success in the perception of the representatives of Generation $Y$

\begin{tabular}{|c|c|c|c|c|c|c|}
\hline Are there any costs of achieving Professional success? & Austria & Spain & Poland & Portugal & Russia & Turkey \\
\hline Yes & $88 \%$ & $91 \%$ & $95 \%$ & $87 \%$ & $88 \%$ & $85 \%$ \\
\hline No & $12 \%$ & $7 \%$ & $5 \%$ & $4 \%$ & $13 \%$ & $15 \%$ \\
\hline Lack of answer & $0 \%$ & $2 \%$ & $0 \%$ & $9 \%$ & $0 \%$ & $0 \%$ \\
\hline & $100 \%$ & $100 \%$ & $100 \%$ & $100 \%$ & $100 \%$ & $100 \%$ \\
\hline
\end{tabular}

Source: Own research

Most of them is connected to the private sphere, indicating that the most sacrifice is in terms of family time - this answer was most frequently chosen by all the respondents (see Table 4). Another indication is also in connection with the nonprofessional area (time spent with friends, development of hobbies). While the costs related to work were chosen relatively rarely (friendliness of colleagues, higher requirements).

Table 4. Types of costs of professional success in the perception of the representatives of Generation $Y$

\begin{tabular}{|l|c|c|c|c|c|c|}
\hline Costs of professional success: & Austria & Spain & Poland & Portugal & Russia & Turkey \\
\hline a. Family time & $\mathbf{3 7 , 6 \%}$ & $\mathbf{3 6 , 5 \%}$ & $\mathbf{3 8 , 6 \%}$ & $\mathbf{4 6 , 7 \%}$ & $\mathbf{3 7 , 0} \%$ & $\mathbf{3 4 , 4 \%}$ \\
\hline b. Time with friends & $33,5 \%$ & $19,0 \%$ & $24,2 \%$ & $25,9 \%$ & $25,9 \%$ & $27,9 \%$ \\
\hline c. Development of hobbies & $12,7 \%$ & $24,6 \%$ & $11,0 \%$ & $13,2 \%$ & $25,9 \%$ & $24,6 \%$ \\
\hline d. Social contacts & $0,6 \%$ & $1,6 \%$ & $4,7 \%$ & $4,6 \%$ & $3,7 \%$ & $3,3 \%$ \\
\hline e. friendliness of colleagues & $9,8 \%$ & $2,8 \%$ & $9,3 \%$ & $3,0 \%$ & $3,7 \%$ & $4,9 \%$ \\
\hline f. higher requirements & $5,8 \%$ & $15,5 \%$ & $12,3 \%$ & $6,6 \%$ & $3,7 \%$ & $4,9 \%$ \\
\hline & $100 \%$ & $100 \%$ & $100 \%$ & $100 \%$ & $100 \%$ & $100 \%$ \\
\hline
\end{tabular}

Source: Own research

Structure of responses for all six countries is featured by the lack of similarity. However, the analysis in pairs indicates a significant similarity between the representatives of different countries. 
Table 5. Similarity index of structures (types of costs of professional success in the perception of the representatives of the generation $Y$ )

\begin{tabular}{|c|c|c|c|c|c|c|}
\cline { 2 - 7 } \multicolumn{1}{c|}{} & Austria & Spain & Poland & Portugal & Russia & Turkey \\
\hline Austria & - & & & & & \\
\hline Spain & $77 \%$ & - & & & & \\
\hline Poland & $88 \%$ & $83 \%$ & - & & & \\
\hline Portugal & $86 \%$ & $80 \%$ & $88 \%$ & - & & \\
\hline Russia & $84 \%$ & $88 \%$ & $83 \%$ & $87 \%$ & - & \\
\hline Turkey & $85 \%$ & $87 \%$ & $83 \%$ & $85 \%$ & $96 \%$ & - \\
\hline
\end{tabular}

\section{Source: Own research}

Exceptions are answers of Austrians and Spaniards, which are characterized by a slight similarity index of structures and responses of young Russians and Turks, which show very high similarity (see Table 5).

\subsubsection{Discussion of the results}

The research conducted by Hewitt Associates shows that employee engagement of Generation $Y$ is significantly lower than of the employees representing older age groups [Best Employers Study 2012] and more ready to mobility [Bednarska-Wnuk 2014]. According to E. Stanoch among the key determinants of the low employee engagement of Generation $Y$ one should also mention attachment to the balance between work and private life [Stanoch 2010]. The issue of this balance recently arises particular interest of researchers. On the one hand, there are many reasons that lead us to believe that the contamination of these two areas will be deepened in the direction of professional sphere [Januszkiewicz 2012]. On the other, however, in the characteristics of Generation $Y$ independence and the reluctance to sacrifice is particularly emphasized [Sheahan 2005]. Among the respondents, representatives of Generation $Y$ the vision this balance seems to be a bit disturbed. Apart from young Turks and the Austrians, the achievement of professional success is linked to the disorder of ratio in favor of work.

This is also confirmed by further results showing awareness of the negative consequences achieving professional success may bring. The fact that deserves special attention is that in each group, in the category of sacrifice, there are elements related to private life, including primarily the time spent with family and with friends. Success in the perception of the representatives of generation $Y$ is, therefore, a certain sacrifice, the cost of which affects private life.

With respect to the main research question posed in this article, to what extent the perception of career success model is a unified global pattern, and to what degree it continues to be under the influence of local standards, it must be stated that similarity of structures between individual countries may be a prerequisite to finding that there is a global pattern of career, on the basis of which the representatives of Generation $Y$ are building their idea on how their professional life will look like (in the light of the presented research results - the perception of career success). However, it should be noted that, contrary to common belief, it is not a unified vision and still local factors function as determinants.

\section{Summary}

Career model transformations are a permanent process. It should be assumed that they constitute almost its inherent trait. And yet, they have never had such a dynamic nature and did not include such a broad spectrum of professional activity of an individual. These new conditions in stereotypical recognition of Generation Y, should create a kind of unified global human resources of the future.

The presented research results indicate a quite coherent picture of a professional life of the representatives of generation $\mathrm{Y}$. This coherence is expressed in the observed in all groups tendency to:

- awareness of the cost of professional success (over $80 \%$ of respondents)

- placement of costs of professional success in the private area

- perceptron of the danger of contamination of family life

However, the detailed analysis of the results leads to a conclusion that this is only a certain tendency, in which one can find different characteristics for representatives of various nationalities. Similarity index of structures of all the groups for each of the analyzed traits indicates no similarity or minor similarity in the distribution of traits in the studied collective bodies. 
The presented results of the research, due to the sample selection cannot be considered as representative. Therefore, their conclusions should be taken with caution, as the observation of trends, which may in the future lead to indepth research and analysis in this area. Bearing, however, in mind these differences, it should be noted that the presented model of analysis of changes and their consequences for the new paradigm of career of an individual, does not cover the catalogue of issues that should be discussed in detail. It should only be interpreted as a certain simplification, that to insufficient extent allows the identification and explanation of the direction and strength of relations.

\section{References}

Bańka A. (2007). Globalizacja pracy i kariery a procesy identyfikacji społecznej i indywidualnej. In M. Górnik-Durose, B. Kożusznik B. (Eds.), Perspektywy psychologii pracy. Wydawnictwo Uniwersytetu Śląskiego, Katowice.

Bednarska-Wnuk I. (2014). Mobilność w optyce młodych osób - na przykładzie Polski i Portugalii, Edukacja Ekonomistów i Menedżerów. Problemy. Innowacje. Projekty (1), pp. 93-109, Szkoła Główna Handlowa w Warszawie - Oficyna Wydawnicza.

Best Employers Study [Online] Available: http://www.hrtrendy.pl/2011/11/14/zaangazowanie-pracownikow-w-rekach-menedzerow/ (January 9, 20120

Hislop D., Axtell C., Daniels K.(2008). The challenge of remote working. In S. Susan, C.L. Cooper (Eds.) Personnel psychology. Oxford University Press, New York, pp. 566-590.

Januszkiewicz K. (2012), Pokolenie Y - dylematy charakterystyki, In P. Wachowiak (Eds.) Człowiek w organizacji. Teoria i praktyka, Szkoła Główna Handlowa w Warszawie, pp. 75-82,

Pahl R. (2008). Neuroza sukcesu. In P. Sztompka, M. Boguni-Borowska M. (Eds.) Socjologia codzienności, Wydawnictwo Znak, Kraków, pp. 934-957.

Sheahan, P. (2005). Generation Y: thriving and surviving with Generation Y at work, Hardy Grant, Prahran.

Stanoch E. (2010). Generation Y in the labor market, Barvard Business Review Poland, October, pp. 74-75.

Zydel R. (2010). Young people in a distorting mirror, Barvard Business Review Poland, October, pp. 55-67. 